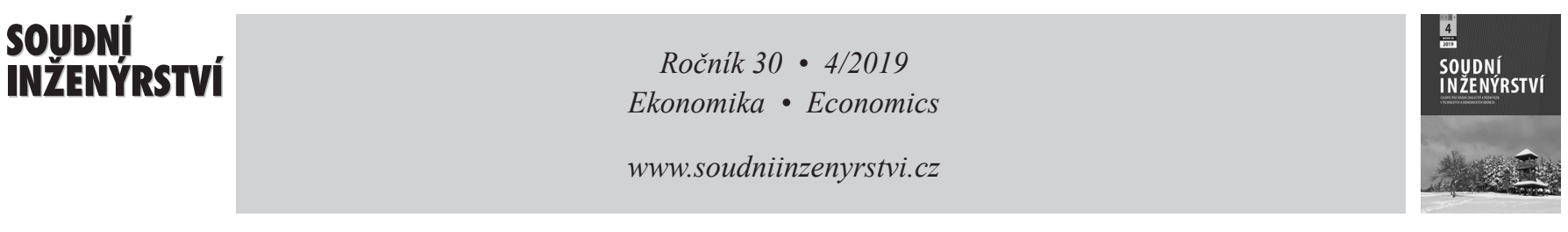

\title{
Hodnotenie výkonnosti podniku
}

\author{
Business Performance Assessment \\ Stanislava Strelcová ${ }^{*}$, Jozef Klučka, Alexander Kelíšek
}

Žilinská univerzita v Žiline, Fakulta bezpečnostného inžinierstva

\begin{abstract}
Abstrakt
Hodnotenie výkonnosti podniku sa stáva neodmyslitel'nou súčast'ou manažérskych systémov podniku. Dochádza pri ňom k zist'ovaniu miery zhodnotenia vložených prostriedkov. V minulosti sa pri tom uplatňovali predovšetkým finančno-ekonomické ukazovatele. Moderné metódy využívajú kvalitatívne a časové ukazovatele, ktoré čo najvýstižnejšie zachytávajú kl'účové oblasti a procesy v podniku. Hodnotenie výkonnosti podniku rieši problémy rôznych skupín zainteresovaných strán: vlastníci vyžadujú maximálne zhodnotenie investícií; investori hl'adajú investíciu s vysokým potenciálom rastu; výkonný manažment chce definovat' aktivity, ktoré sa zdajú byt' neefektívne alebo chcú nájst' riešenia podporujúce rast spoločnosti. Ciel'om článku je, na základe dotazníkového prieskumu, zistit', do akej miery sa uplatňuje hodnotenie výkonnosti podniku v slovenských podmienkach.
\end{abstract}

Klíčová slova: výkonnost' podniku, manažment výkonnosti, hodnotenie výkonnosti, podnik, štatistický výskum.

\section{1. ÚVOD}

Súčasné podnikatel'ské prostredie sa vyznačuje početnými zmenami, dynamikou a neustále sa meniacimi determinantmi podnikatel'ského prostredia. Uvedené zmeny čoraz viac zasahujú do podnikatel'ských činností, a preto je nevyhnutné vhodne merat' a hodnotit' ako výkonnost' podniku, tak aj jeho finančné zdravie [1].

Hodnotenie výkonnosti je významný manažérsky nástroj. Je založené na hodnotení zamestnanca, procesu, zariadenia alebo iných činitel'ov ktoré odrážajú vývoj smerom $\mathrm{k}$ určeným ciel'om podniku. Aplikáciou v podniku môžu majitelia identifikovat' ziskové a neziskové aktivity. Hodnotenie výkonnosti je zamerané na minulost' - ohodnotenie dosiahnutých výsledkov na základe poznania minulosti vedie, môže viest' k modifikácii stratégie, ktorá sa zameriava na budúcnost'.

\begin{abstract}
The business performance assessment is becoming an integral part of company management systems. In fact, it is based on measurement of rate of return on investment. Mostly, the financial and economic indicators have been applied in the past. Modern methods use qualitative and time-based indicators that capture key areas and processes in the enterprise as much as possible. The assessment of the company performance solves issues of various groups of stakeholders: the owners require maximal appreciation of the investments; the investors look for an investment with a high growth potential; the executive management wants to define activities which appear to be ineffective or wants to find solutions supporting the company growth. The aim of the article is, on the basis of a questionnaire survey, to find out the range of the business performance assessment in companies in Slovak conditions.
\end{abstract}

Keywords: business performance, performance management, performance assessment, enterprises, statistical research.

\section{VÝKONNOSŤ PODNIKU}

Meranie výkonnosti podniku nie je samoúčelné. Ciel'om nie je merat', ale umožnit' zlepšovanie výkonnosti. Meranie pomocou určitých ukazovatel'ov musí byt' súčast'ou neustále prebiehajúceho programu analyzovania, hodnotenia a zlepšovania prevádzkovej výkonnosti podnikovými manažérmi za účelom dosahovania prosperity [2].

Ak chápeme podnik ako ekonomicko-sociálny systém, ktorého činnost' je determinovaná vnútorným aj vonkajším prostredím, potom je zrejmé, že aj hodnotenie výkonnosti podniku vyžaduje ucelený prístup. Obsah a štruktúru systému hodnotenia výkonnosti znázorňuje obr. 1.

Výkonnost' podniku je možné definovat' ako spôsob, respektíve priebeh, akým skúmaný subjekt vykonáva určitú činnost' 


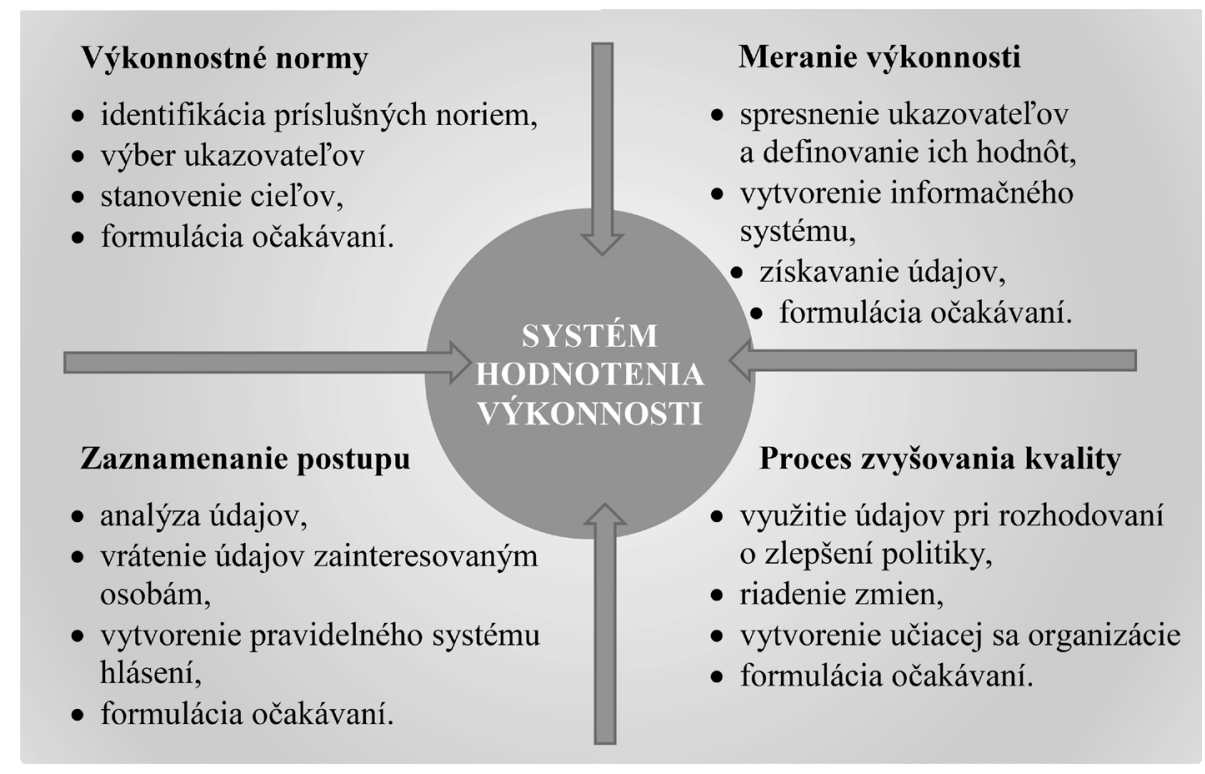

Obr. 1 Štruktúra a obsah systému hodnotenia výkonnosti [3].

Fig. 1 Structure and content of the system for assessing the performance.

na základe podobnosti s referenčným spôsobom vykonávania tejto činnosti. Interpretácia charakteristiky výkonnosti podniku predpokladá schopnost' porovnania skúmaného a referenčného javu z hl'adiska stanovenej škály. Ak by sme aplikovali uvedenú definíciu do polohy podniku a podnikatel'skej činnosti, výkonnost' podniku možno definovat' ako spôsob vykonávania podnikatel'skej činnosti na základe podobnosti s referenčným rámcom iných podnikatel'ských subjektov, ktoré vykonávajú podnikatel'skú činnost'. Ide tak o porovnávanie skúmaného (porovnávaného) podniku s inými podnikmi na základe vybraných referenčných prvkov.

Pre meranie výkonnosti podniku sa najčastejšie využíva finančná analýza. Finančná analýza podniku je mnohokrát považovaná za primárny nástroj finančného riadenia podniku. Zabezpečuje určité prepojenie medzi predpokladanými dosiahnutými ciel'mi a skutočným stavom. Finančná analýza je úzko prepojená s účtovníctvom podniku, nakol'ko jednotlivé finančné výkazy predstavujú dôležitý informačný zdroj pre finančné rozhodovanie podniku.

Finančná analýza „zahŕňa ohodnotenie minulosti, súčasnosti a budúcnosti. Porovnáva výsledky niekol'kých období, a na základe toho ohodnocuje vývojový trend hospodárenia podniku. Jej ciel'om je zistit' finančné zdravie podniku, identifikovat' slabiny a vyzdvihnút' silné stránky. Finančná analýza slúži pre porovnávanie v čase, s inými podnikmi, alebo s odvetvím. Informácie, ktoré poskytuje, slúžia pre veritel’ov, akcionárov, manažment, investorov, obchodných partnerov, štátne inštitúcie, zamestnancov, audítorov a verejnost'. Sú to hlavne finančné informácie, medzi ktoré patria účtovné výkazy, predpovede finančných analytikov a vrcholového vedenia, burzové spravodajstvo hospodárske správy informačných médií a ostatné informácie, ako napríklad oficiálne ekonomické štatistiky, komentáre odbornej tlače, nezávislé hodnotenia a prognózy.“ [4]

Hodnotenie výkonnosti podniku je orientované do minulosti a realizované najčastejšie prostredníctvom analýzy ex-post, ale čoraz viac sa do popredia dostáva analýza ex-ante, na základe ktorej je možné predpovedat' budúci vývoj podniku. Hodnotenie výkonnosti podniku sa tak stáva súčast'ou manažmentu rizík. Prostredníctvom finančno-ekonomickej analýzy a vhodne stanovených indikátorov je možné hodnotit' súvislosti a identifikovat' potenciálne riziká ohrozujúce podnik, či správne určit' symptómy, ktoré podmieňujú vznik podnikovej krízy a zabezpečit' tak systém včasného varovania $\mathrm{v}$ podniku.

Kislingerová hodnotí výkonnost' podniku tromi spôsobmi. Bud' na základe ukazovatel’ov likvidity, aktivity, kapitálovej štruktúry, rentability a trhovej hodnoty, alebo prostredníctvo pyramídových rozkladov ukazovatel'ov (známe sú napr. DuPontove pyramídy), či použitím predikčného modelu, ktorý je syntézou čiastkových ukazovatel'ov [4].

Bez ohl'adu na to, aký spôsob hodnotenia výkonnosti si podnikový manažment zvolí, mal by dodržiavat' určitú následnost' krokov. Viacerí autori [5, 6, 7, 8, 9] vnímajú hodnotenie výkonnosti ako prostriedok na identifikáciu finančných rizík. Z ich pohl'adu musí hodnotenie výkonnosti zahŕňat’ nasledovné činnosti:

- výber a stručná definícia objektu porovnávania,

- výber objektov, s ktorými je možné objekt porovnávat',

- výber jednotlivých indikátorov a ukazovatel'ov,

- stanovenie rozsahu akceptovatel'nosti hodnôt indikátorov a ukazovatel'ov,

- vyhodnotenie analýzy a identifikovanie jednotlivých rizík.

Hudymačová pokladá za významné najmä: konkretizáciu podnikatel'ských ciel'ov, výber finančných a nefinančných ukazovatel'ov, stanovenie ciel'ových hodnôt a vyhodnotenie analýzy [10].

Výkonnost' podniku však nemusí byt' hodnotená len podnikovými manažérmi, ktorí chcú identifikovat' aktivity javiace sa ako neefektívne, alebo chcú nájst' riešenia podporujúce rast podniku, ale aj zo strany rôznorodých skupín stakeholderov. Vlastníci požadujú maximálne zhodnotenie svojich investícií. Investori hl'adajú investíciu s vysokým potenciálom rastu. Kupujúci sa pri hodnotení zameriavajú na to, či podnik dokáže uspokojit' ich potreby a či 
dokáže pružne reagovat' na meniace sa požiadavky. Predávajúci sa pri hodnotení výkonnosti obchodného partnera zameriavajú na zabezpečenie vyhovujúcich obchodných podmienok.

\section{UKAZOVATELE HODNOTENIA VÝKONNOSTI}

Pri zostavovaní súboru ukazovatel'ov je potrebné si uvedomit', že budú využívané podnikovým manažmentom ako nástroj na zhodnotenie naplnenia stanovených ciel'ov a tým aj výkonnosti podniku. Označujú sa ako kl’učové indikátory výkonnosti, tzv. KPI (key performance indicators). Hudson, Smart, Bourne uvádzajú, že KPI by mali:

- byt' prepojené s podnikovou stratégiou,

- byt' určené jasne so zrejmým účelom,

- byt' relevantné a l'ahko udržiavatel'né,

- byt' jednoduché na pochopenie a používanie,

- poskytovat' rýchlu a presnú spätnú väzbu,

- prepojit' operácie so strategickými ciel'mi a stimulovat' neustále zlepšovanie [11].

Zjednodušene je možné povedat', že stanovenie kl'účových indikátorov výkonnosti by malo rešpektovat' techniku SMART. To znamená, indikátory by mali byt' špecifické, jednoznačne známe (S), meratel'né (M), dosiahnutel'né (A), relevantné, významné pre hodnotenie $(\mathrm{R})$ a časovo definované $(\mathrm{T})$.
Cocca, Alberti okrem už uvedených charakteristík klúǔcových indikátorov doplńajú potrebu podpory integrácie a orientáciu na plánovanie budúcej výkonnosti. Inými slovami: základné otázky pri stanovení indikátorov výkonnosti sú: čo merat', kto bude merat' a mat' zodpovednost' za uchovanie dát, ako bude vyzerat' výstupný report, ako má byt' spracovaná reakcia na výsledky vrátane kompetencií. Taktiež je možné vyvodit' súvislost' medzi klúčovými indikátormi výkonnosti a ukazovatel'mi využívanými v rámci kontextu business inteligence. Táto súvislost' je zrejmá z pohl'adu uplatňovaných analýz dát. Môže íst' o analýzu deskriptívnu, ktorou sa identifikujú vzt’ahy medzi skúmanými premennými (ukazovatel'mi) a preskriptívnu, kedy sa $\mathrm{z}$ dát spracúvajú predpovede o budúcnosti [12].

Trendom však je orientácia na budúcnost' - to znamená z minulých a súčasných dát odvodit’ informáciu, ktorá je podporná v manažérskom procese a teda ovplyvňuje budúcnost' podniku.

\section{HODNOTENIE VÝKONNOSTI V PRAXI}

Ciel'om autorov príspevku bolo nielen poukázat' na dôležitost' zavedenia systému hodnotenia výkonnosti do podnikov, ale aj snaha pochopit' problémy podnikatel’ov, ktoré s hodnotením výkonnosti súvisia. Z tohto dôvodu uskutočnili dotazníkové zist'ovanie, na ktorom sa zúčastnilo 150 podnikov.
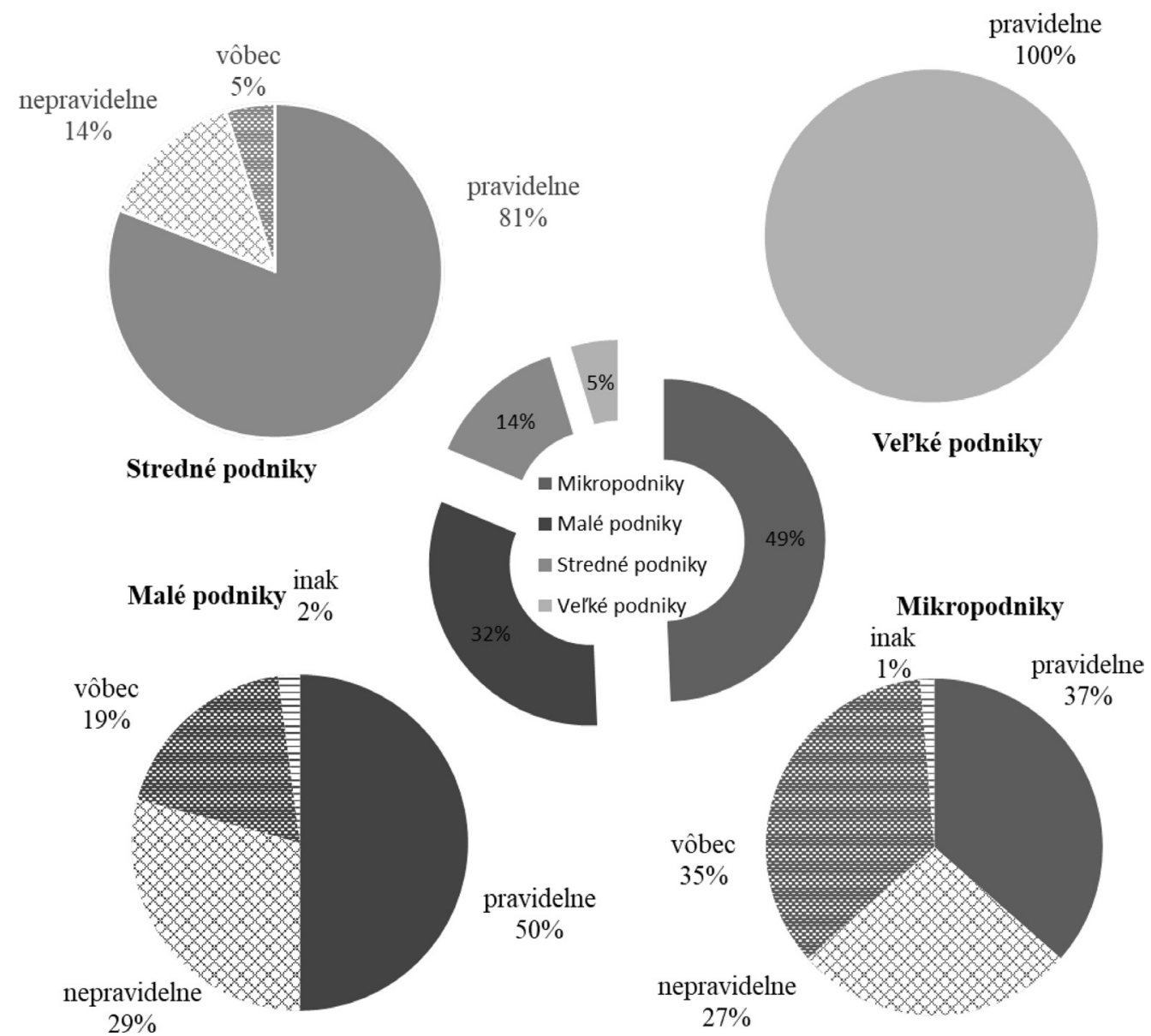

Obr. 2 Vel'kostná štruktúra podnikov a ich odpoved' na otázku: Ako často sa zaoberáte hodnotením výkonnosti podniku?

Fig. 2 Size structure of enterprises and their answer to the question: How often do you realize the business performance assessment? 
Dotazník bol rozdelený na tri časti. Prvá charakterizovala podnik, jeho vel'kost', vlastnícku formu, odvetvie činnosti a d'alšie kritériá. Druhá čast', bola zameraná na konkrétne otázky z oblasti hodnotenia výkonnosti a v poslednej časti boli respondenti požiadaní, aby priradili dôležitost' jednotlivým faktorom konkurencieschopnosti a podnikovej výkonnosti.

Dotazníkového zist'ovania sa zúčastnilo 74 mikropodnikov, 48 malých podnikov, 21 stredných podnikov a 7 vel'kých podnikov. Najčastejší výskyt v skúmanej vzorke majú priemyselné podniky (33 podnikov), podniky zaoberajúce sa vel'koobchodom a maloobchodom; opravou motorových vozidiel a motocyklov ( 30 podnikov) a podniky pôsobiace v stavebníctve ( 22 podnikov).

Z celkového počtu podnikov až 75 podnikov ( $50 \%$ ) vykonáva hodnotenie výkonnosti pravidelne, 37 podnikov (25\%) vykonáva hodnotenie výkonnosti nepravidelne a 2 podniky vykonávajú hodnotenie inak (1\%). Možno teda konštatovat', že $76 \%$, t. j. 114 podnikov vykonáva hodnotenie svojej výkonnosti. Obr. 2 znázorňuje štruktúru odpovedí aj z hl'adiska vel'kosti oslovených podnikov.

Z obr. 2 vyplýva, že takmer $1 / 4$, čo je až 36 podnikov, nevykonáva hodnotenie výkonnosti vôbec. Autorov preto zaujímali dôvody, prečo tomu tak je. Za najčastejšie dôvody nevykonávania hodnotenia výkonnosti uvádzajú podniky pochybnosti o jeho zmysluplnosti (16 podnikov) a iné dôvody (11 podnikov), ktoré však bližšie nešpecifikovali. $\mathrm{V}$ dvoch podnikoch respondenti pocit'ujú nedostatok znalostí a v šiestich nedostatok odborníkov v problematike. Jeden z podnikov, ktorému bola otázka určená, na ňu nezodpovedal vôbec.

Pri otázke na dôležitost' prikladanú jednotlivým záujmovým skupinám (stakeholderom) boli ako najvýznamnejšie skupiny vyhodnotené: zákazníci (v $91 \%$ podnikov), vlastníci (v 80\% podnikov) a zamestnanci (v $74 \%$ podnikov). Za najmenej dôležitých považujú podniky veritel'ov. Najdôležitejšími kritériami pri hodnotení významnosti stakeholderov sú pre podniky: schopnost' (sila) stakeholderov ovplyvnit' chod podniku, legitimita ich vzt'ahov a naliehavost' ich požiadaviek (31 podnikov), aktuálne strategické ciele podniku (26 podnikov) ako aj ich kombinácia (23 podnikov). Je však potrebné zmienit', že až 20 podnikov sa rozhodovalo intuitívne a 23 podnikov vplyv stakeholderov nevyhodnocuje.

Autori venovali pozornost' aj dôvodom, pre ktoré podniky uskutočňujú hodnotenie výkonnosti podniku. Podniky, ktoré uskutočňujú hodnotenie výkonnosti (114 podnikov), mohli pre stanovené položky hodnotenia určit' ich bodovú dôležitost', pričom 1 bod znamenal najmenej dôležitá a 5 bodov najdôležitejšia. Analýza bola vykonaná bez ohl'adu na vel'kostnú kategóriu podniku a jej výsledky sú zhrnuté v tab. 1. Na otázku odpovedalo len 112 podnikov a viac ako polovica opýtaných považuje za dôležité

Tab. 1 Dôvody pre zavedenie hodnotenia výkonnosti v podnikoch.

Tab. 1 Reasons for implementing business performance assessment.

\begin{tabular}{lccc}
\hline \multirow{2}{*}{ Položka hodnotenia } & \multicolumn{3}{c}{ Prisúdená dôležitost' } \\
\cline { 2 - 4 } & $\begin{array}{c}\text { Málo dôležitá } \\
(\mathbf{1 - 2})\end{array}$ & $\begin{array}{c}\text { Priemerná } \\
\mathbf{( 3 )}\end{array}$ & $\begin{array}{c}\text { Dôležitá } \\
\mathbf{( 4 - 5 )}\end{array}$ \\
\hline Finančné ukazovatele & 5 & 9 & 98 \\
Prevádzkové ukazovatele & 6 & 18 & 88 \\
Ukazovatele finančnej & 11 & 19 & 82 \\
štruktúry a solventnosti & 20 & 32 & 60 \\
Investičné ukazovatele & 18 & 29 & 65 \\
Ukazovatele cash-flow & 19 & 43 & 50 \\
Marketingové ukazovatele & 25 & 48 & 39 \\
Makroekonomické ukazovatele & &
\end{tabular}

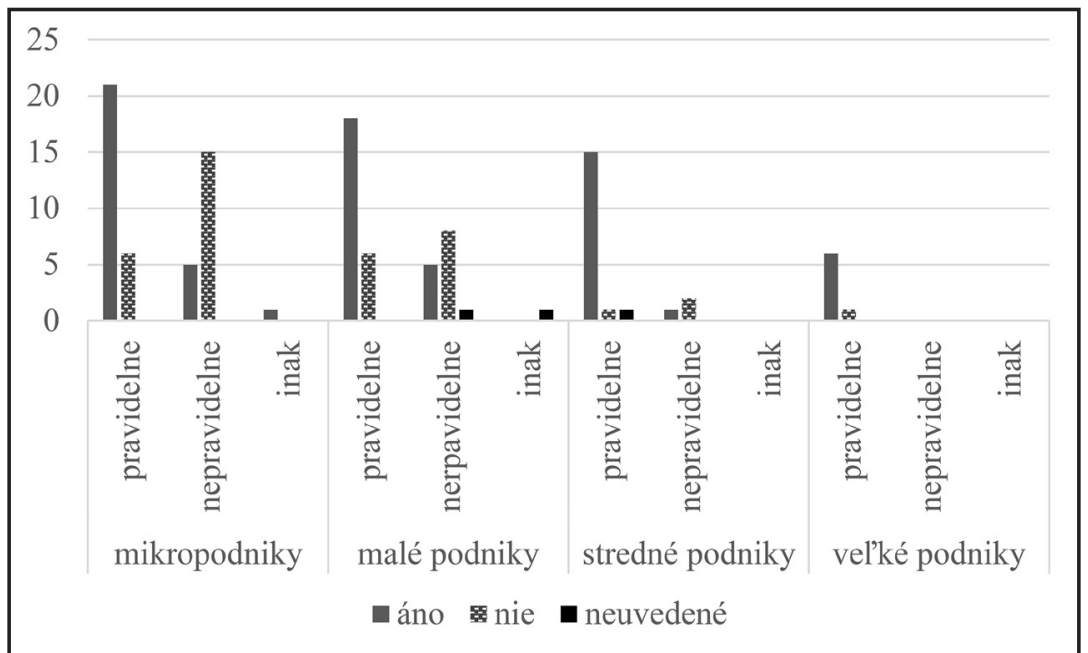

Obr. 3 Vplyv pravidelnosti opakovania hodnotenia výkonnosti podniku na určenie zodpovédného zamestnanca

Fig. 3 Impact of regularity of business performance assessment on the determination of responsible employee. 
Tab. 2 Dôležitost' faktorov konkurencieschopnosti a podnikovej výkonnosti.

Tab. 2 Importance of competitiveness and business performance factors.

\begin{tabular}{lccc}
\hline \multirow{2}{*}{$\begin{array}{l}\text { Faktory konkurencieschopnosti a podnikovej } \\
\text { yýkonnosti }\end{array}$} & $\begin{array}{c}\text { Málo dôležitý } \\
\mathbf{( 1 - 2 )}\end{array}$ & $\begin{array}{c}\text { Priemerný } \\
\mathbf{( 3 )}\end{array}$ & $\begin{array}{c}\text { Dôležitý } \\
\text { (4-5) }\end{array}$ \\
\hline Inovačná schopnost' a technologický rozvoj & 24 & 38 & 88 \\
Marketingové a distribučné faktory & 16 & 51 & 83 \\
Výrobné faktory, plánovanie a riadenie výroby & 30 & 40 & 80 \\
Faktory l'udských zdrojov & 14 & 38 & 98 \\
Technologické faktory & 25 & 41 & 84 \\
Ekologické faktory & 37 & 47 & 66 \\
Sociálne faktory vplývajúce na kúpyschopnost' dopytu & 17 & 51 & 82 \\
Makroekonomické faktory & 32 & 65 & 53 \\
Politické faktory a stabilita & 64 & 53 & 33 \\
Legislatívne faktory & 25 & 62 & 63 \\
\hline
\end{tabular}

takmer všetky položky hodnotenia s výnimkou marketingových a makroekonomických ukazovatel'ov.

Na otázku, či je za spracovanie hodnotenia výkonnosti určený zodpovedný pracovník, odpovedalo len 111 podnikov (3 podniky neuviedli odpoved'). Z týchto podnikov má na hodnotenie výkonnosti podniku vyčleneného pracovníka 72 podnikov v pomere mikro : malý : stredný : vel'ký podnik $=27: 23: 16$ : 6. Toto je možné považovat' za pomerne prekvapivý výsledok, pretože $\mathrm{v}$ malých, ale predovšetkým $\mathrm{v}$ mikropodnikoch je obvyklé kumulovat' viaceré povinnosti a funkcie na jediného pracovníka.

Autori d’alej skúmali aj vzt'ah medzi frekvenciou vykonávania hodnotenia výkonnosti a tým, či má podnik na túto činnost' vyčleneného zamestnanca. Výsledky sú znázornené v obr. 3 .

$\mathrm{Z}$ obr. 3 je zrejmé, že špecialistu na vykonávanie hodnotenia výkonnosti podniku zamestnávajú predovšetkým podniky, v ktorých sa hodnotenie výkonnosti uskutočňuje pravidelne, bez ohl'adu na ich vel'kost' (60 podnikov).

V poslednej časti dotazníkového prieskumu autori požiadali podniky o vyjadrenie názoru na faktory konkurencieschopnosti a podnikovej výkonnosti. Podniky mohli stanoveným faktorom priradit' bodovú dôležitost', pričom 1 bod znamenal najmenej dôležitý a 5 bodov najdôležitejší.

$\mathrm{Na}$ otázku reagovalo všetkých 150 oslovených podnikov. Za najdôležitejší faktor považuje väčšina podnikov l'udské zdroje. Ďalšími dôležitými zdrojmi sú inovačná schopnost' a technologický rozvoj, technologické faktory a marketingové a distribučné faktory. Pri porovnaní výsledkov z tab. 1 a 2 je možné si všimnút' rozpor medzi názormi respondentov. V tab. 1 boli marketingové ukazovatele považované za dôležité len pre približne $45 \%$ podnikov. $\mathrm{V}$ tab. 2 patria marketingové a distribučné faktory medzi dôležité pre $55 \%$ podnikov. Môže to by spôsobené skutočnost'ou, že v tab. 2 sú zahrnuté aj odpovede tých podnikov, ktoré nehodnotia riziko vôbec.

\section{ZÁVER}

Termín výkonnost' označuje schopnost' podnikatel'ského subjektu dosiahnut' určité výsledky, ktoré sú udržatel'né a porovnatel'né s konkurenciou. [13]. Možno teda skonštatovat', že sledovanie výkonnosti podniku je podmienkou úspešného podnikania. Predpokladom pre jeho realizáciu je stanovenie vhodných metód a kritérií, pomocou ktorých sa bude výkonnost' podniku posudzovat'. Mnohé podnikatel'ské subjekty si ešte stále dostatočne neuvedomujú, aké dôležité je sledovat' nielen finančnoekonomické ukazovatele [14, 1]. Svoju pozornost' by mali venovat' zist'ovaniu hodnôt prevádzkových, personálnych, časových a d'alších ukazovatel'ov. Okrem toho je potrebné si uvedomit', že tradičné metódy sú založené na analýze výsledkov dosahovaných v minulosti a preto neumožňujú objektívne posúdit' výkonnost' podniku v budúcnosti. Preto sa v súčasnosti do popredia dostávajú metódy orientované na zvýšenie hodnoty výkonnosti do budúcnosti, napr. EVA, MVA, CFROI,... ako aj systémy, ktoré podporujú stratégiu podnikov, napr. BSC alebo EFQM [15].

Napriek tomu, že hodnotenie výkonnosti podniku umožňuje podnikom zlepšit' ich výkony a konkurencieschopnost', dotazníkovým prieskumom sa autorom potvrdilo, že hodnotenie výkonnosti na Slovensku je využívané hlavne vo vel'kých a stredných podnikoch. Vel'ká čast' podnikov, ktoré hodnotenie výkonnosti nevykonávajú, ho nepovažuje za zmysluplné, príp. nezamestnáva odborníkov z tejto oblasti.

Pri vyhodnotení otázok týkajúcich sa ukazovatel'ov a faktorov výkonnosti, ktoré sú pre podniky zaujímavé, bolo zistené, že stále prevažujú finančné ukazovatele, ale za dôležité sú považované aj prevádzkové ukazovatele a ako najvýznamnejší faktor konkurencieschopnosti sú uvádzané l'udské zdroje.

V d'alšom riešení projektu sa autori zamerali na konkretizáciu odpovedí podnikov. Svoju pozornost' zamerali na detailnejšie zistenie dôvodov pre zavedenie hodnotenia výkonnosti v podnikoch, problémov, ktoré museli podniky pri zavádzaní hodnotenia riešit' ako aj vzt'ahom systému hodnotenia výkonnosti $\mathrm{k}$ iným manažérskym systémom $\mathrm{v}$ podniku.

\section{POĎAKOVANIE}

Táto publikácia vznikla vd’aka podpore projektu,,SK-AT-2017-0003 Hodnotenie výkonnosti malých a stredných podnikov v SR a Rakúsku“. 


\section{LITERATURA}

[1] WAGNER, J. Měrení výkonnosti: jak měřit, vyhodnocovat a využivat informace o podnikové výkonnosti. Grada Publishing, Praha, 2009, 256 s. ISBN 978-80247-2924-4.

[2] HAMMER, M. Jak zlepšit provozní výkonnost. In: Moderní ř́zení, 58(9), s. 32-36. ISSN 0026-8720.

[3] Turning Point. From Silos to Systems: Using Performance Management to Improve thePublic's Health, 2003. Dostupné na: http://www.phf.org/resourcestools/Documents/PM_Self_Assess Tool.pdf

[4] KISLINGEROVÁ, E. Podnikv časech krize. Grada Publishing, Praha, 2009, 208 s. ISBN 978-80-247-3136-0.

[5] RAJNOHA, R. a kol. Meranie a riadenie výkonnosti podnikov. Technická univerzita vo Zvolene, Zvolen, 2013, 313 s., ISBN 978-80-2282-554-2.

[6] LESÁKOVÁ, L. Metódy hodnotenia malých a stredných podnikov. EF UMB, Banská Bystrica, 2004, 124 s. ISBN 80-8055-914-7.

[7] NEUMANOVÁ, A. kol.: Podniková diagnostika. Iura Edition, Bratislava, 2012, 201 s. ISBN 978-80-8078-464-5.

[8] KNÁPKOVÁ, A., PAVELKOVÁ, D., ŠTEKER, K. Finanční analýza, komplexní průvodce s príklady. 2. rozšiřené vydání. Grada publishing, Praha, 2013, 240 s. ISBN 978-80-2474-456-8.

[9] SEDLÁČEK, J. Finanční analýza podniku. Computer Press, Brno, 2009, 154 s. ISBN 978-0251-1830-6.
[10] HUDYMAČOVÁ, M., HILA, M. Výkonnost' podniku. In: QMagazín: internetový časopis o jakosti [online]. 2011, říjen, ISSN 1213-0451. Dostupné na: http://www.fmmi.vsb.cz/639/ clanek.html

[11] HUDSON, M., SMART, A., BOURNE, M. Theory and parctice in SME performance measurement systems. International Journal of Operations \&Production Management, (21)8, 2001, 1096-1115 s., MCB University Press. ISBN 0144-3577.

[12] COCCA, P., ALBERTI, M. A framework to assess performance measurement systems in SMEs. International Journal of Productivity and Performance Management, (59)2, 2010, 186-200 s., Emerald insight. ISSN 1741-0401.

[13] KISLINGEROVÁ, E. 2009. Jak měřit výkonnost podniku v časech krize. In: Úspěch: produktivita \& inovace v souvislostech, API, (4)4, s. 15-16, Želevčice. ISSN 1803-5183.

[14] FIBÍROVÁ, J., ŠOLJAKOVÁ, L. Hodnotové nástroje rrizeni a měreni výkonnosti podniku. Aspi Publishing, Praha, 2005, 263 s. ISBN 80-7357-084-X.

[15] DURKÁČOVÁ, M. Prístupy k hodnoteniu výkonnosti podniku a jeho procesov v kontexte ekonomického vývoja [online\}. In: Zbornik z 13. medzinárodnej vedeckej konferencie Trendy a inovativne prístupy v podnikových procesoch ,2010“. Technická univerzita v Košiciach, Košice. [cit. 2018-04-10]. Dostupné z: https://www.sjf.tuke.sk/umpadi/taipvpp/2010/index. files/clanky\%20PDF/DURKACOVA_2.pdf

\section{Správná citace:}

STRELCOVÁ, S., KLUČKA, J., KELÍŠEK, A. Hodnotenie výkonnosti podniku. Soudní inženýrství, 2019, 30(4), $12-17$.

DOI: http://dx.doi.org./10.13164/SI.2019.4.12. ISSN 1211-443X. 